\title{
A lição da música (notas sobre Nietzsche e Rousseau)
}

\author{
Maria João Mayer Branco*
}

Resumo: O texto explora as afinidades que podem ser encontradas entre o pensamento de Nietzsche e o de Rousseau a partir da análise do interesse de ambos pela música. Não escamoteando o que os separa, procura-se esclarecer as razões deste interesse e a sua relação quer com a preocupação que partilham acerca da cultura ocidental moderna, quer com crise da subjectividade que essa cultura parece acarretar.

Palavras-chave: música - filosofia - Rousseau - modernidade auto-conhecimento - amor.

Sim, por vezes a música soa, no interior de um mundo novo e assombrado, como a linguagem de uma era desaparecida, vindo tarde demais. (...) toda a música verdadeiramente significativa é canto de cisne (VM/OS 171, KSA $2.450){ }^{1}$

1.

No parágrafo 334 de A Gaia Ciência, Nietzsche propõe a ideia de que é preciso aprender a ouvir música. A primeira parte do texto descreve os três passos dessa aprendizagem:

Assim se passa em nós com a música: em primeiro lugar tem de se aprender a ouvir uma forma, uma melodia, discerni-la pelo ouvido

\footnotetext{
* Universidade Nova de Lisboa, Portugal. Correio eletrônico: maria_joao_branco@yahoo.com

1 Os textos de Nietzsche são citados segundo a edição portuguesa das Obras Escolhidas, Círculo de Leitores, Lisboa, 1996 (dirigida por António Marques), salvo indicação contrária. Neste caso, seguiu-se a edição brasileira, Friedrich Nietzsche, Humano, demasiado humano II, Companhia das Letras, São Paulo, 2008 (tradução, notas e posfácio de Paulo César de Souza).
} 
e distingui-la, isolá-la e delimitá-la como uma vida em si; depois é preciso esforço e boa vontade para a suportar apesar da sua estranheza, praticar a paciência com o seu aspecto e expressão, o bom coração com a sua singularidade; finalmente, chega o momento em que estamos habituados a ela, em que a esperamos, em que pressentimos que nos faria falta se nos faltasse; e então opera ela o seu domínio e fascínio mais e mais, e não acaba antes de nos tornarmos os seus humildes e enlevados amantes, que já não querem mais nada no mundo senão a ela e só a ela $(F W / G C 334, \mathrm{KSA} 3.559)$.

A aprendizagem aqui em jogo começa com a "distinção", a "delimitação" ou o "isolamento" de uma figura ou melodia [eine Figur und Weise], como se fosse, escreve Nietzsche, "uma vida em si" [ein Leben für sich]. Segue-se o "esforço e boa vontade" para suportar a sua "estranheza", que requer "paciência com o seu aspecto" e "bom coração com a sua singularidade". Por fim, chega o momento em que esperamos por aquela música e sentimos "que nos faria falta, se nos faltasse", o momento em que, acrescenta ainda Nietzsche, nos tornamos os seus "amantes" e nada mais queremos "senão a ela e só a ela".

O texto propõe uma escuta musical que não se esgota no primeiro contacto e consiste, antes, num exercício continuado ou repetido, que admite diferentes estádios e requer tempo, esforço e dedicação. Esta modalidade de escuta tem de ser aprendida, mas não parece consistir nem numa aquisição de conhecimentos específicos, nem na aplicação de uma qualquer técnica ou saber determinado. Ao que tudo indica, Nietzsche não se dirige aqui a especialistas, a musicólogos, compositores ou instrumentistas, por exemplo. Pelo contrário, defendendo que ouvir música é uma experiência que requer aprendizagem, Nietzsche parece dirigir-se a quem quer que calhe lê-lo, a qualquer pessoa, leiga ou não em música, referindo-se, não a um conjunto de conhecimentos definidos, mas a uma disponibilidade para escutar que é, em princípio, acessível a qualquer um.

No texto, a relação do ouvinte com a melodia é apresentada 
como análoga à relação de alguém com outra pessoa. A melodia é descrita como um ser vivo ou dotado de "uma vida em si", capaz de suscitar, repetida e inesgotavelmente, o fascínio e até o amor de quem a escuta. Enquanto tal, acrescenta Nietzsche, esta vida fascinante traz também ao ouvinte (que se torna seu aprendiz ou "amante") descobertas a respeito de si próprio, diferenças tais de si a si que, na descrição que é feita, mal reconhecemos uma mesma pessoa nas diferentes fases da escuta. Ou seja, no que respeita ao ouvinte, o processo de aprendizagem aqui descrito - um processo de auto-aprendizagem, como se tornará mais claro adiante - parece também ele poder ser potencialmente interminável e cambiante, admitindo repetições que revelam diferenças até naquilo que é mais próximo ou familiar, supostamente mais conhecido do mesmo ouvinte: ele mesmo. O desejo de voltar a escutar o que já se ouviu não revela apenas que há mais para ouvir além de tudo o que se escutou; esse desejo mostra igualmente que na escuta o escutador se revela a si próprio já que, de estranho, o ouvinte pode passar a ser, ou descobrir-se como, um amante da melodia, aquele que já não passa sem ela e para quem a sua escuta se torna íntima necessidade.

O texto intitula-se "É preciso aprender a amar", e a segunda parte esclarece que aprender a ouvir música é, por excelência, o exemplo de uma aprendizagem mais ampla, que Nietzsche estima "necessária", que outra não é senão a aprendizagem do amor:

Mas não se passa assim conosco só com a música: precisamente assim aprendemos nós a amar todas as coisas que amamos agora. Acabamos sempre por ser recompensados pela nossa boa vontade, a nossa paciência, equidade, ternura para com o que é estranho, na medida em que essa estranheza lentamente despe o seu véu e se revela com uma nova e indizível beleza: é a sua gratidão pela nossa hospitalidade. Também quem a si próprio se ama, tê-lo-á aprendido por esta via, não há outra. Também é preciso aprender o amor ( $F W / G C 334$, KSA 3.559).

Ouvir música surge, então, como uma propedêutica ou uma 
iniciação, como um caso particular, mas exemplar, de uma aprendizagem mais geral, a aprendizagem do amor. O título do texto parece confirmar esta interpretação, embora Nietzsche termine salientando a necessidade de aprender um tipo de amor específico, no qual porventura consiste a condição de qualquer possibilidade amorosa, e que é o amor de si. Segundo a indicação do texto, o amor que é preciso aprender começa com o contrário de uma familiaridade, ou seja, começa com uma "estranheza", com uma diferenciação ou uma distinção. Daí o esforço que é necessário fazer, a aprendizagem a que Nietzsche se refere, indicando que nem esta forma de amor é, por assim dizer, natural.

A ideia do texto é justamente esta, a de que amar (uma melodia, outra pessoa, nós mesmos) não é um fenômeno natural. E a hipótese que aqui se sugere é a de que é justamente neste ponto que uma aproximação com Rousseau pode ser estabelecida. Semelhante aproximação vai certamente ao arrepio das críticas que Nietzsche dirige a Rousseau ao longo da sua obra ${ }^{2}$, as quais, no entanto, não anulam, malgrado todas as diferenças que separam estes pensadores, pelo menos duas afinidades fundamentais: o amor de ambos pela música ${ }^{3}$ e a preocupação que partilham com a crise e o destino da nossa civilização ${ }^{4}$. O que aqui se propõe não é, de forma alguma, escamotear o que separa Nietzsche de Rousseau; em vez disso, e tomando como mote o parágrafo 334 de $A$ gaia ciência, pretende-se antes concentrar a atenção no privilégio que o pensamento de ambos concede à música, e no valor filosófico que, com

2 Cf., a título de exemplo, MAI/HH I 463, KSA 2.299, M/A, Prefácio 3, KSA 3.12, GD/CI, Incursões de um Extemporâneo, 3 e 48, KSA 6.112/150 .

3 Referindo-se a Rousseau e Nietzsche, Lacoue-Labarthe interroga-se a respeito destas "duas ocorrências da história (moderna) da filosofia [nas quais] uma certa compulsão auto-biográfica (...) se associou a uma 'obsessão musical' [hantise musicale]". Cf. LACOUE-LABARTHE, Philippe. "L'écho du sujet" in Pour n'en pas finir. Écrits sur la musique. Paris: Christian Bourgois, 2015, p. 141.

4 ANSELL PEARSON, K. Nietzsche Contra Rousseau: A Study of Nietzsche's Moral and Political Thought. New York: Cambridge University Press, 1991. 
Branco, M. J. M.

consequências muito diversas, mas nem por isso absolutamente incompatíveis, ambos atribuíram à escuta musical.

2.

Tanto Nietzsche, como Rousseau pensam a música na sua relação com a linguagem e a partir da forma como a civilização moderna enfraqueceu essa relação. Para ambos, a história do Ocidente é a história de um declínio, particularmente manifesto na progressiva perturbação do equilíbrio, sempre instável, mas exigido pela vida humana, entre natureza e cultura. Ambos consideram que, na modernidade, as formas civilizacionais desse equilíbrio privilegiaram desmedidamente a racionalidade, dando forma a uma perigosa exigência de inteligibilidade e à transformação da imagem do ser humano num ser racional, capaz de dominar, e até de corrigir, a realidade que lhe resiste ${ }^{5}$.

N'O nascimento da tragédia, Nietzsche chama a esta perspectiva "racionalismo socrático", analisando os seus sintomas na compreensão moderna da arte e, em particular, da música. Uma importante parte dessa análise concentra-se no parágrafo 19, onde Nietzsche considera de modo crítico o "socratismo estético" patente nas criações musicais da sua época e o seu princípio segundo o qual "Tudo deve ser inteligível para ser belo" (GT/NT 12, KSA 1.81). Este é patente, muito em especial, na ópera moderna e no seu uso do recitativo. Nietzsche considera que aquele último revela uma "tendência extra-artística", pois concede maior importância ao texto e à inteligibilidade das palavras do que ao "sentido musical do ouvinte", tal que "o cantor vai ao encontro do ouvinte, que quer apreender nitidamente a palavra sob o canto" (GT/NT 19, KSA

5 Cf. o famoso passo sobre a "ânsia de conhecimento insaciável e optimista", em que Nietzsche fala da "crença inabalável em como o pensamento, seguindo o fio condutor da causalidade, atinge os mais profundos abismos do ser, e de que o pensamento seria capaz, não apenas de conhecer, mas mesmo de corrigir o ser" e de como esta crença se "acrescenta como instinto à ciência" (GT/NT 15, KSA 1.97). 
1.120). Satisfazendo a exigência de inteligibilidade e facilitando "a compreensão da palavra", os inventores da ópera acreditavam ter assim conseguido "re-despertar a música mais plena de expressão", que suscitava o prazer de compreender entendido como uma "conciliação" e evocava a possibilidade de uma convivência harmônica entre os homens baseada na ideia de uma inteligibilidade universal, na qual a música teria um dia consistido. Assim imaginavam, na perspectiva de Nietzsche, ser possível regressar às origens da música, ao "mundo originário" que a vira nascer. N'O nascimento da tragédia a ópera moderna é, portanto, retratada como correspondendo a "uma entrega ao devaneio de haver voltado a descer aos inícios paradisíacos da humanidade" (GT/NT 19, KSA 1.120). É nesta medida que ela manifesta o racionalismo socrático e o consequente optimismo que lhe presidiu, segundo o qual a pureza originária e a verdade da música eram, não apenas cognoscíveis, mas também recuperáveis por meio das composições operáticas: o recitativo representava "a linguagem redescoberta" do "homem primitivo", e a ópera "o país reencontrado daquele ser bom, idílico ou heróico" (GT/NT 19, KSA 1.120).

Nietzsche considera que a ópera nasce numa cultura "idílica" e não "elegíaca" (noções que toma de empréstimo a Schiller), uma vez que, nela, "o ideal não é sentido como algo inatingido, nem a natureza como algo perdido" (GT/NT 19, KSA 1.120). Pelo contrário, a ópera corresponde ao sentimento de que teria existido "uma época primitiva do homem, na qual ele teria estado situado no coração da natureza, tendo atingido em simultâneo com essa naturalidade o ideal da humanidade". Assim, "apenas teríamos de nos despojar de algumas coisas para nos reconhecermos a nós próprios como sendo esse homem primitivo" (GT/NT 19, KSA 1.120). A ópera moderna representa, portanto, a convicção de que é possível regressar à "sintonia de natureza e ideal, a uma realidade idílica”, bem como "a crença consoladora de que o 'homem em si' (...) teria sempre de acabar por reencontrar-se no caso de porventura se 
haver realmente perdido durante algum tempo, fruto daquele optimismo que se eleva aqui das profundezas da cosmovisão socrática" (GT/NT 19, KSA 1.120).

Da cultura da ópera é, então, característica a convicção de que o estado originário ou "natural" do humano não é algo "perdido" ou "inatingível" e, portanto, um objecto de tristeza, mas algo realmente re-constitutível ou recuperável, ou seja, "um objecto de alegria" ao qual é, efectiva ou operaticamente, possível aceder (GT/NT 19, KSA 1.120). Por esta razão, acrescenta ainda Nietzsche, à ópera é totalmente estranha para "aquela dor elegíaca de uma perda eterna", sendo-lhe antes característica "a serenidade do eterno reencontro, o cômodo prazer de uma realidade idílica que ao menos pode ser a qualquer instante imaginada como sendo real", mas que, na verdade, não é, segundo Nietzsche, senão "uma frivolidade" quando confrontada "com as verdadeiras cenas primitivas dos primórdios da humanidade" e com "a terrível seriedade da verdadeira natureza" (GT/NT 19, KSA 1.120). Porque responde a tendências extra-artísticas e tem origens num "optimismo" alheio ao "reino estético", a ópera moderna corresponde à degeneração da "suprema missão da arte" - "redimir o olhar de relance para o horror da noite e salvar o sujeito das convulsões da vontade através do bálsamo terapêutico da aparência" - numa "tendência de entretenimento, vazia e dispersiva" de carácter "formalmente lúdico e divertido" (GT/NT 19, KSA 1.120).

Em tudo isto encontramos um oposto da escuta musical que Nietzsche descreve no parágrafo 334 de A gaia ciência, quer dizer, encontramos uma música e uma escuta da música que, em vez de promover fascínio e aprendizagem infinita, "transforma a fruição musical na retórica intelectual da paixão, em verbo e som" e "dita as suas leis com o sereno optimismo do homem teórico" (GT/NT 19, KSA 1.120). O espectador da ópera não é um aprendiz, mas um conhecedor, e não descobre, portanto, na música que escuta, senão o que já sabe ou julga saber, também a respeito de si mesmo. Por esta 
razão, nos termos de $O$ nascimento da tragédia, a ópera é alheia ao espírito trágico da música, bem como à própria tragédia em que procurou um exemplo a imitar, pois na ópera a inteligibilidade do que é dito na música aparece, 'socrática' e optimisticamente, como o garante de um acesso à verdade e às origens de uma existência humana ainda não corrompida e feliz.

Ora, a ideia de um regresso efectivo a este "paraíso da humanidade", como Nietzsche lhe chama na única passagem d'O nascimento da tragédia em que Rousseau é citado (GT/NT 3, KSA 1.34), é uma ideia moderna, e ingênua, de uma época que via em Émile uma suposta harmonia e unidade primordial do homem com a natureza. Como é bem sabido, O nascimento da tragédia contesta, não apenas a simplicidade atribuída a semelhante estado originário, mas também, e talvez sobretudo, a possibilidade de um regresso a esse mesmo idílio. Muitos anos depois de publicar a sua primeira obra, Nietzsche mantém as críticas a esta fantasia moderna, não poupando nas palavras quando ataca Rousseau, a quem considera como o primeiro responsável pelas ideias de progresso e da possibilidade de um "regresso à natureza". No entanto, é forçoso reconhecer que, ao contrário do que encontramos na cultura moderna e operática e na sua tendência optimista e idílica, as descrições e referências de Rousseau ao momento de união do homem com a natureza não inspiram, de modo nenhum, "a serenidade do primeiro encontro", e muito menos "o cômodo prazer de uma realidade idílica". De facto, se a caracterização que Rousseau faz do estado natural ou originário da humanidade revela, de algum modo, um "objecto de alegria", a verdade é que a evocação desse objecto não é acompanhada de nenhum entusiasmo optimista, mas daquilo que Nietzsche designa como a "dor elegíaca de uma perda eterna"7 $\mathrm{Na}$

6 GD/CI, Incursões de um Extemporâneo, 3 e 48, KSA 6.150.

7 Acerca do sentimento elegíaco que caracteriza os escritos de Rousseau, cf. SIMON, Julia. "Rousseau and Aesthetic Modernity: Music's Power of Redention". In: Eighteenth Century Music, 2, pp. 41-56, 2005. 
verdade, ao invés do retrato que Nietzsche faz do autor de Émile, Rousseau descreve a modernidade como um período declinante da civilização ocidental e fá-lo destituído de quaisquer ilusões progressistas. E isto torna-se particularmente claro nos textos que Rousseau dedicou à música, e onde a cultura moderna é descrita, como procurarei agora indicar, de uma forma muito mais próxima da de Nietzsche do que aquilo que este último parece fazer crer aos seus leitores.

3.

Rousseau nunca escondeu as suas ideias acerca do que considerava serem os efeitos negativos do progresso civilizacional ${ }^{8}$. Já em 1750, em resposta ao concurso lançado pela Académie des sciences, arts et belles-lettres de Dijon e bem ao arrepio das tendências iluministas da época, defendera, no Discours sur les sciences et les arts, que o aperfeiçoamento das ciências e das artes não contribuíra para superar a fragmentação crescente e a experiência de alienação típica das sociedades do século XVIII, tendo antes tido o efeito de corromper os costumes e as virtudes. Do ponto de vista de Rousseau, o desenvolvimento científico e artístico não trouxe às sociedades modernas um melhoramento dos males da vida individual e colectiva, tendo antes sido concomitante com o desenvolvimento das convenções artificiais, das vaidades e das aparências, acarretando o triunfo da frivolidade e da opinião. Assim, a existir qualquer progresso no sentido iluminista do termo, não era de esperar que esse chegasse por meio do cultivo da ciência e das artes, ou seja, de um cultivo da "ordem do saber" e da razão, mas do cultivo daquilo a que Rousseau chama a "ordem moral" .

As críticas que Rousseau dirige à ideia de um progresso da

8 Cf, a este respeito, STAROBINSKI, Jean. Jean-Jacques Rousseau. La transparence et l'obstacle. Paris: Gallimard, 1971 e SIMON, Julia. "Rousseau and Aesthetic Modernity: Music's Power of Redention". In: Eighteenth Century Music, 2, pp. 41-56, 2005.

9 Starobinski, op. cit., p. 15. 
civilização rumo ao saber e ao conhecimento devem-se, em grande medida, ao modo como entendeu a racionalidade, o seu lugar e o seu papel na constituição humana, e exprimem-se muito significativamente no Ensaio sobre a origem das línguas e nas reflexões que aí desenvolve acerca da música. Tal como acontece n'O nascimento da tragédia, este ensaio estabelece um paralelo entre a história da música e a história da civilização ocidental, tal que as considerações de Rousseau sobre a importância ou o valor geral da música e sobre as circunstâncias em que ela era composta e escutada na época moderna, se enquadram no seu diagnóstico da crise da cultura provocada pela ideologia do progresso e pela tendência racionalista suas contemporâneas. Também à maneira do que acontece n'O nascimento da tragédia, é no contexto desse mesmo diagnóstico que Rousseau associa o declínio da música (e da linguagem) a uma progressiva valorização da razão na cultura moderna (ao "estudo da filosofia" e ao "progresso do raciocínio"10), da qual decorreu uma desvalorização da melodia em favor da harmonia:

Tendo a melodia sido esquecida e tendo a atenção do músico sido inteiramente voltada para a harmonia (...) não é de espantar (...) que a música tenha perdido para nós quase toda a sua energia. (...) por fim, limitada ao efeito puramente físico da vibração dos sons, a música foi privada dos efeitos morais que produzia quando era duplamente a voz da natureza. ${ }^{11}$

A defesa, por parte de Rousseau, de uma primazia da melodia em detrimento do valor da harmonia decorre da polêmica que o opôs a Rameau quanto à natureza ou à origem da música ${ }^{12}$. Enquanto Rameau defendia que na origem da música estava um princípio físico universal e natural, a saber, a harmonia produzida pela resso-

10 ROUSSEAU, Jean-Jacques. Essai sur l'origine des langues (ed. Jean Starobinski). Paris: Gallimard, 1990, cap. XIX, p. 138. Doravante, Essai, seguido do número do capítulo e do número da página desta edição.

11 Essai, cap. XIX, p. 142.

12 A este respeito, cf. SCOTT, John T., "Rousseau and the Melodious Language of Freedom". In: The Journal of Politics, Vol. 59, No. 3 (Aug.,), 1997, p. 813 ss. 
nância de um corpo, para Rousseau a música tem origem na capacidade humana de exprimir e comunicar as paixões que a melodia reproduz ou imita através da voz humana. Assim, segundo Rameau, a causa ou origem da música, bem como os seus efeitos, são físicos, pelo que a música é, como qualquer outro fenômeno da natureza, passível de ser cientificamente conhecida e estudada. Considerada desta perspectiva, a música consiste, então, nas proporções sonoras que definem a harmonia e cuja estabilidade matemática está para além, ou é condição, das circunstâncias temporais a que qualquer melodia está sujeita. Dito de outro modo, para Rameau a existência da melodia deriva ou é subsidiária da existência de leis harmônicas, "natural" ou universalmente válidas, e independentes, embora acessíveis, ao entendimento ou à racionalidade humana.

Do ponto de vista de Rousseau, esta compreensão daquilo em que a música consiste é redutora e bem representativa do declínio do espírito de uma época que se esforçava por materializar todas as operações da alma, e na qual os assuntos humanos eram considerados a partir da perspectiva meramente naturalista da Física. Ao contrário de Rameau, Rousseau defende que a música não é um fenômeno estritamente físico, e que a nossa sensibilidade à música não é um fenômeno estritamente natural, uma vez que a física do som não fornece uma explicação satisfatória para a origem da música, nem para o prazer e o sentido que continuamos a retirar dela. Como Rousseau esclarece, a música afecta o ouvinte não como uma série de sons que podem ser derivados do corps sonore através de ratios determináveis como vibrações que alcançam o ouvido, mas como sinais das nossas afecções e sentimentos:

Enquanto quisermos considerar os sons apenas pela vibração que excitam nos nossos nervos, não obteremos os verdadeiros princípios da música e do seu poder sobre os corações. Os sons da melodia não agem sobre nós apenas como sons, mas como indícios das nossas afecções, dos nossos sentimentos; é assim que eles suscitam em nós os movimentos que 
exprimem e dos quais ali reconhecemos uma imagem. ${ }^{13}$

Assim, a teoria de Rameau acerca do corpo sonoro não toma em consideração aquilo que é especificamente humano na música, a saber, o facto de os seus efeitos mais poderosos não operarem através de sensações físicas, mas de uma sensibilidade moral. $\mathrm{O}$ prazer que a escuta de uma melodia proporciona não advém das propriedades físicas dos sons que a compõem, mas da relação íntima desses sons com paixões humanas, relação essa que explica "o poder da música sobre os corações" $"$.

Para Rousseau, portanto, a música não é um fenômeno puramente físico ou natural, mas moral, quer dizer, cultural. Por essa razão, ela está mais longe da ciência e da razão do que da arte e dos sentimentos, e é justamente isto que leva Rousseau a defender a primazia da melodia sobre a harmonia. A sua ideia é a de que a melodia imita as inflexões da voz e exprime, assim, as paixões humanas, sendo, por essa razão, congenial à humanidade. Mais precisamente ainda, a melodia "não imita apenas, ela fala, e a sua linguagem inarticulada, mas viva, ardente, apaixonada tem cem vezes mais energia do que a própria palavra" ${ }^{15}$. Ao invés, a harmonia "separa o canto da palavra"16 e essa separação rompe com a união originária que, segundo Rousseau, ligava a música à linguagem a "origem comum" de "versos, canções e discursos"17.

Na linguagem desencadeada pelas paixões residia, então, para Rousseau, a origem da música, e a melodia é a sua expressão originária, ou melhor, a expressão de um estado originário da humanidade em que a linguagem não se distinguia do canto. No entanto, importa esclarecer que Rousseau não defende que a melodia é uma forma natural, se "natural" significa livre de toda e qualquer

13 Essai, cap. XV, p. 126.

14 Essai, cap. XV, p. 126.

15 Essai, cap. 14, p. 124.

16 Essai, cap. 14, p. 124.

17 Essai, cap. 12, p. 114. 
convenção. Pelo contrário, no seu pensamento a música encontra-se no coração de um processo de aculturação originária, que é propriamente o processo de humanização do ser humano, de tal modo que se pode mesmo afirmar que a sua concepção da música tem por base uma "antropologia"18. De facto, a melodia exprime as paixões através da imitação de inflexões vocais e acentuações, mas estas acentuações estão intimamente ligadas, não a uma natureza que existe no mundo exterior, mas à constituição do ser humano como participante de uma comunidade ou de uma cultura.

Este aspecto torna-se claro quando se atenta mais demoradamente nas considerações de Rousseau acerca da melodia e da escuta de uma melodia, em particular na sua ideia de que o que está em causa nessa escuta não é nenhum tipo de necessidade natural, mas o reconhecimento de um ser humano por outro, reconhecimento esse que Rousseau associa à escuta de uma voz que canta. Nas suas palavras,

assim que signos vocais vos tocam o ouvido, anunciam um ser semelhante a vós, eles são, por assim dizer, os órgãos da alma, e se também pintam a solidão, dizem que não estais sós. Os pássaros assobiam, só o homem canta, e não é possível ouvir nem o canto, nem a sinfonia, sem que se diga imediatamente Está aqui outro ser sensível. ${ }^{19}$

A linguagem vocal, ou muito simplesmente a voz, e muito em particular a voz cantada ou o canto, não resulta, então, de causas naturais ou estritamente físicas, uma vez que falar e cantar não são propriamente necessidades, não servem a sobrevivência dos homens. A voz, a fala e o canto têm antes origem nas paixões, às quais Rousseau também chama "necessidades morais", pois enquanto as actividades ligadas à sobrevivência são silenciosas e solitárias, as que estão relacionadas com as paixões são comunitárias e relacionam os seres humanos uns com os outros. A voz não constitui,

18 É esta a tese de Downing A. Thomas. (Cf. THOMAS, Downing A. Music and the Origins of Language. Theories of the French Enlightment. Cambridge University Press, 1995, pp. 82-142.

19 Essai, cap. 16, p. 132. 
portanto, um fenômeno natural, sendo antes algo especificamente humano, no sentido em que só se torna possível pela constituição de uma humanidade comum ou de uma comunidade ${ }^{20}$. Eis porque o Ensaio reúne a música e a linguagem, a canção e o discurso, todos constituídos por sons vocais, através da sua relação comum às paixões: reúne-os como algo que é particular à natureza humana, a saber, a capacidade e a necessidade de comunicar com o seu semelhante.

4.

Embora em termos muito distintos, podemos encontrar ressonâncias desta ideia no parágrafo 334 de A Gaia ciência que começámos por citar. Não apenas Nietzsche se concentra no poder ou valor de uma melodia, como fala dela, como notamos acima, como se fosse uma pessoa, uma "vida em si", e da escuta dela como um exercício amoroso, quer dizer, não racional, mas, e em certa medida à maneira de Rousseau - ou, pelo menos, não certamente à maneira de Rameau -, passional ou afectiva. Assim, e a despeito do modo como, as mais das vezes - embora não todas as vezes ${ }^{21}-$, Nietzsche se contrapõe violentamente a Rousseau, no que à música diz respeito a sua oposição parece atenuar-se, como o confronto do já citado parágrafo19 de $O$ nascimento da tragédia com o tom elegíaco de Rousseau parece, de resto, provar.

Ao aforismo 334 de A gaia ciência segue-se, porém, um texto que, a uma primeira leitura, se distingue categoricamente da perspectiva que Rousseau apresenta acerca da música, e em particular das suas objecções a Rameau. O texto chama-se "Viva a Física!" (FW/GC 335, KSA 3.560). Nietzsche começa por avançar algumas considerações sobre a dificuldade e raridade de um verdadeiro exercício de observação de si ou de auto-conhecimento e com a

20 Cf, a este respeito, Downing A. Thomas, op. cit.

21 Cf. $M / A$ 481, KSA 3.285. 
declaração de que "Cada um é em si mesmo, o mais longínquo de si próprio", parecendo concluir com uma apologia das leis da Física com as quais, como foi descrito acima, Rameau explicava a origem e a natureza da música. Contudo, o sentido da oposição que o texto de Nietzsche estabelece entre a Física e a Moral, a qual, privilegiando a primeira e não a segunda, aparentemente inverte a oposição defendida por Rousseau no Ensaio, só se esclarece devidamente quando lida à luz da moral que ali se encontra explicitamente em jogo, ou seja, quando lida à luz da moral kantiana e da universalidade formal ou abstracta que lhe é própria e que ela postula. Assim consideradas, torna-se possível estabelecer uma analogia entre as críticas que Nietzsche dirige à pura formalidade do imperativo categórico neste texto e as críticas feitas por Rousseau à universalidade metafísica atribuída por Rameau ao princípio físico que regula a harmonia musical. De facto, a Física defendida n'A gaia ciência não é a dos que sentem "o seu juízo como lei geral", mas antes a dos que querem tornar-se naqueles que são, quer dizer, dos "únicos, os incomparáveis, os que se criam a si próprios" em vez de remeterem a singularidade dos seus actos e juízos para leis válidas para todo e qualquer um. Estes têm, então, de se tornar físicos num sentido muito distinto, e até contrário ao que Rameau professava, e Nietzsche acrescenta ainda, ecoando o texto que imediatamente precede, que os novos físicos terão de se tornar "os melhores alunos e descobridores de tudo o que é legítimo e necessário no mundo", ou seja, têm de se tornar "físicos" no sentido de serem "criadores"

Um alcance porventura mais pleno do texto e do entendimento da Física que nele está em jogo, tal como da aventada afinidade de Nietzsche com as críticas de Rousseau a Rameau, surge quando ele é confrontado com uma outra passagem de A gaia ciência, des-

22 Para uma análise mais demorada deste texto, cf. NANCY, Jean-Luc. “’Our Probity!' On Truth in the Moral Sense in Nietzsche". In: Rickers, Laurence A. (ed.). Looking after Nietzsche. State University of New York Press, 1990, pp. 67-87. 
ta feita o parágrafo 373. Aqui Nietzsche ataca a visão puramente científica dos "materialistas da natureza", para os quais "o mundo tem de ter o seu equivalente e medida no pensamento humano, (...) num 'mundo da verdade', ao qual se conseguiu de modo definitivo aceder com a ajuda da nossa pequena e quadrada razão humana", e que reduzem a existência "a um exercício de aprendiz de cálculo e trabalho de casa para matemáticos" ( FW/GC 373, KSA 3.624). Nietzsche critica as interpretações científicas e mecanicistas do mundo que permitem "contar, calcular, pesar, ver e tocar e nada mais", perguntando se a única coisa que podemos compreender e conhecer da existência não será, antes pelo contrário, aquilo que nela é "sensível". Mas a inicialmente insuspeitada afinidade com Rousseau torna-se ainda mais perceptível quando, acusando a mistura do mecanicismo com a Filosofia que é típica "hoje em dia" e também a suposição de que "a mecânica é a doutrina dos primeiros e últimos mandamentos sobre os quais toda a existência deve ser construída", Nietzsche esclarece o seu ponto de vista comparando a existência humana à música:

Supondo que se apreciava o valor de uma música de acordo com quanto dela se pudesse contabilizar e reduzir a fórmulas — que absurda seria uma tal avaliação 'científica' da música! Que se teria entendido, compreendido e reconhecido nela! Nada, absolutamente nada daquilo que nela é verdadeiramente 'música'!...(FW/GC 373, KSA 3.624)

O espírito destas declarações parece acordar-se com as críticas tecidas por Rousseau a uma concepção não apenas científica, racional e metafísica, mas também, e para voltarmos aos termos do parágrafo 19 de $O$ nascimento da tragédia, progressista e optimista da música. Tal significa que, malgrado as diferenças que os separam no que à moral diz respeito - também elas certamente merecedoras de revisitação -, no que toca às origens da música, tanto para Nietzsche, como para Rousseau, elas não devem ser procuradas 
nas "esferas" todos os avanços da ciência, continuamos a chamar humana.

Ora, desta vida não é própria apenas a linguagem e a relação com outros seres humanos, mas uma temporalidade não (meta-)física (ou não "esférica"), um tempo finito com o qual a eternidade dos princípios de Rameau contrastam. Além de tudo o que se disse já a seu respeito, a primazia que Rousseau dá à melodia no Ensaio indica igualmente, e muito explicitamente, este aspecto essencial. No seu entender, a melodia é mais fundamental do que a harmonia porque para aceder à harmonia, à 'verdade' da música, é necessário aceder à verdade do som que apenas é revelada temporalmente na melodia. Aquilo que Rousseau nos convida, portanto, a pensar é que pode até ser que sem uma harmonia atemporal e originária, universalmente válida e racionalmente cognoscível, a existência de toda e qualquer melodia fica efectivamente comprometida, a verdade, porém, é que "essa harmonia intemporal só pode ser experimentada temporalmente" ${ }^{24}$, ou seja, melodicamente. A melodia tem precisamente este carácter de uma unidade que se desdobra no tempo, ela é "uma unidade sucessiva que se relaciona com o sujeito, e pela qual todas as partes, bem ligadas, compõem um todo único, do qual percebemos o conjunto e todas as relações" ${ }^{25}$. É impossível perceber esta unidade isolando as suas partes sem compreender as suas mútuas relações na sequência sucessiva em que surgem, pois que é próprio da melodia é o movimento que articula entre si as notas que a compõem, quer dizer, a sua sucessão no tempo ou a sua passagem. Entendendo a melodia, não como uma "vida em si" e uma vida que passa desdobrando-se no tempo, mas como

23 Cf. M/A 100, KSA 3.89 onde Nietzsche compara a crença na significação moral da existência com a crença na música das esferas.

24 Cf. DAVIS, Michael. "The Music of Reason in Rousseau's Essay on the Origin of Languages". In: The Review of Politics 74, 2012, pp. 389-402.

25 Rousseau, Oeuvres complètes, volume 5, 1143 citado em SIMON, Julia. "Rousseau and Aesthetic Modernity: Music's Power of Redention" in: Eighteenth Century Music, 2005 , p. 53. 
um mero objecto entre outros concebido por princípios extra-temporais, a cosmologia musical de Rameau perde, portanto, de vista a natureza temporal e temporária do melódico. Quer dizer, ela perde de vista a natureza não natural que distingue a melodia dos objectos, por assim dizer, meramente "físicos", ao mesmo tempo em que distingue, entre esses objectos, os sujeitos humanos e o tempo que os define, a saber, o tempo da passagem. Tal como, na melodia, as notas isoladamente percebidas ou consideradas não exprimem nem comunicam nada, não fazem qualquer sentido nem dizem o que é que a melodia é, também assim a vida humana, a vida concreta que é vivida por cada um de nós - entendidos como “os únicos, os incomparáveis" -, não pode ser entendida, nem conhecida, quando decomposta nas suas componentes materiais ou físicas. Se temos de nos conhecer, como Nietzsche escreveu, e se temos de aprender a fazê-lo, essa aprendizagem assemelha-se efectivamente a aprender a ouvir uma melodia porque o tempo que essa escuta implica ensina-nos que também nós somos uma vida que passa, quer dizer, que se perde. É nessa medida que nos desconhecemos e estamos longe de nós próprios, na medida em que estamos sempre a passar, de forma que não nos podemos constituir como um objecto de conhecimento. Sendo estranhos a nós próprios, resta-nos uma incessante tarefa, que é menos de auto-conhecimento do que auto-descoberta. Esta ideia surge igualmente no início do Discurso sobre a origem e os fundamentos da desigualdade entre os homens ${ }^{26}$, onde Rousseau defende que conhecemos melhor os restantes objectos exteriores do que a nós mesmos e que o conhecimento humano mais útil, mas menos avançado, é o auto-conhecimento. Tanto o Ensaio, como o Discurso remetem para um "estado natural" do humano, para a sua "constituição originária" onde este se sentia, por assim dizer, presente e não distante de si mesmo, e caracterizam esse estado como perdido ou tornado, por circunstâncias exterio-

26 Ideia defendida por Michael Davis no trabalho já referido, e que subscrevemos. 
res, históricas e sociais, irreconhecível. Em tal estado originário, e agora desaparecido, os homens não viviam febrilmente fora de si mesmos, escravos daquilo que Rousseau designa como amour propre, e sentiam alegria na sua existência, um sentimento a que Rousseau chama amour de soi, amor de si. No contexto que é aqui o nosso, estas expressões recordam-nos imediatamente o que é dito no parágrafo 334 de $A$ gaia ciência sobre aprender a amar-se a si mesmo. No entanto, Rousseau apresenta este estado como sendo, simultaneamente, um estado de perfeito contentamento e um objecto de profunda nostalgia. O contentamento, porém, só é inteligível à luz da nostalgia. Não sendo determinado no tempo, ou sendo apresentado como um estado intemporal, fora do curso do tempo e da história, o estado originário de acesso imediato a si e de amor a si mesmo só adquire, por assim dizer, vida quando se torna parte de uma sequência temporal e passa ser concebido, não como um objecto fixo e estável, passível de ser conhecido e, como diz Nietzsche no aforismo 373 de $A$ gaia ciência, contabilizado e reduzido a fórmulas, mas como um objecto distante e de difícil acesso, alvo de um esforço e de uma procura, do nosso profundo anseio. É precisamente a esta apresentação de um estado de perfeita harmonia que apenas aparece como harmonioso por via de um anseio nostálgico que Rousseau chama melodia. A sua emergência indica a emergência da subjectividade humana através do encontro fortuito com outro ser, e a sua escuta evoca um contacto originário e autêntico, mas irremediavelmente perdido, com outros e consigo mesmo.

Se, portanto, na origem da vida humana se encontra, como Rousseau defende, a linguagem e a relação consigo e com outros seres, e se essa origem é o que explica que a melodia esteja na origem da música, defender isto não corresponde a defender que a música nos faz efectivamente regressar, como Nietzsche acusa a ópera moderna de propor, a um estádio originário e paradisíaco ou natural. É indubitável que o Essai e a importância que aí é dada à melodia estabelecem uma ligação com um estado originário, do 
qual a melodia é apresentada como um potencial catalisador. Mas em vez da coincidência consigo mesmo e da presença a si, o que o Ensaio descreve é uma inelutável e contínua separação da origem, o incessante movimento de diferenciação no qual consiste a vida subjectiva, a sua heterogeneidade e as suas contradições, que qualquer sequência melódica espelha. O que quer que esta vida seja, ela não é natural. E talvez mais decisivamente do que tudo o resto para o que aqui apenas tentamos começar a explorar, o que Rousseau diz da música implica que, se ela fala, ela pede-nos que sejamos humanos, mostrando-nos que não o somos 'naturalmente'. Dito de outro modo, e de um modo que Nietzsche certamente não repudiaria, a lição da música, aquilo que ela nos diz quando canta, é que "o natural é, tal como o humano, aprendido." 27

\begin{abstract}
The text aims at exploring the affinities that might be found between Nietzsche's and Rousseau's thought through an analysis of their common interest in music. Without ignoring the discrepancies between both of them, it tries to enlighten the reasons behind this interest and their shared concern for modern western culture, as well as for the subjective crisis that this culture seems to cause.

Keywords: music - philosophy - Rousseau - modernity - selfknowledge - love.
\end{abstract}

\title{
Referências bibliográficas
}

ANSELL PEARSON, K. Nietzsche Contra Rousseau: A Study of Nietzsche's Moral and Political Thought. New York: Cambridge University Press, 1991.

DAVIS, Michael. “The Music of Reason in Rousseau's Essay on the Origin of Languages". In: The Review of Politics 74, pp. 389-402, 2012.

LACOUE-LABARTHE, Philippe. "L'écho du sujet" in Pour n'en pas finir. Écrits sur la musique. Paris: Christian Bourgois, 2015.

27 STRONG, Tracy B., "Rousseau: Music, Language, and Politics”. In: Chapin, Keith/Clarck, Andrew H. (eds.). Speaking of Music - Adressing the Sonorous, Mew York, Fordham University Press, 2013, p. 95. 
Branco, M. J. M.

NANCY, Jean-Luc. "Our Probity!' On Truth in the Moral Sense in Nietzsche". In: Rickers, Laurence A. (ed.). Looking after Nietzsche. State University of New York Press, pp. 67-87, 1990.

NIETZSCHE, Friedrich. Humano, demasiado humano II. Tradução, notas e posfácio de Paulo César de Souza. São Paulo: Companhia das Letras, 2008.

. Obras Escolhidas. (Dirigida por António Marques). Lisboa: Círculo de Leitores, 1996.

. Sämtliche Werke. Kritische Studienausgabe, herausgegeben von Giorgio Colli und Mazzino Montinari, Deutscher Taschenbuch Verlag, Walter de Gruyter, Berlin, 1999.

ROUSSEAU, Jean-Jacques. Essai sur l'origine des langues (ed. Jean Starobinski), Paris: Gallimard, 1990.

SIMON, Julia. "Rousseau and Aesthetic Modernity: Music's Power of Redention". In: Eighteenth Century Music, 2, pp. 41-56, 2005.

SCOTT, John T., "Rousseau and the Melodious Language of Freedom". In: The Journal of Politics, Vol. 59, No. 3 (Aug.,), pp. 803-829, 1997.

STAROBINSKI, Jean. Jean-Jacques Rousseau. La transparence et l'obstacle. Paris: Gallimard, 1971.

STRONG, Tracy B., “Rousseau: Music, Language, and Politics”. In: Chapin, Keith/Clarck, Andrew H. (eds.). Speaking of Music - Adressing the Sonorous, Mew York, Fordham University Press, 2013.

THOMAS, Downing A. Music and the Origins of Language. Theories of the French Enlightment, Cambridge University Press, 1995.

Artigo recebido para publicação em 12/11/2016.

Artigo aceito para publicação em 12/12/2016. 